\title{
Biological properties of Oncocalyxone A: a review
}

\author{
Propriedades biológicas da Oncocalixona A: uma revisão
}

Propiedades biológicas de la Oncocalyxona A: una revisión

Received: 03/27/2021 | Reviewed: 04/08/2021 | Accept: 04/12/2021 | Published: 04/22/2021

Raí Emanuel da Silva
ORCID: https://orcid.org/0000-0002-4266-0475
Universidade Federal do Piaú, Brazil
E-mail: raiemanuel@ hotmail.com
Fábio de Oliveira Silva Ribeiro
ORCID: https://orcid.org/0000-0002-3916-9239
Universidade de Brasília, Brazil
E-mail: fabioriber2014@ gmail.com
Gisele Santos de Araújo
ORCID: https://orcid.org/0000-0002-1756-6823
Universidade Federal do Delta do Parnaíba, Brazil
E-mail: gisele.araujo92@ @mail.com
Bruno Iles
ORCID: https://orcid.org/0000-0001-6844-7608
Universidade de Brasília, Brazil
E-mail: iles630@gmail.com
Otília Deusdênia Loiola Pessoa
ORCID: https://orcid.org/0000-0002-1617-7586
Universidade Federal do Ceará, Brazil
E-mail: otilialoiola@ @gmail.com
Alyne Rodrigues de Araújo
ORCID: https://orcid.org/0000-0002-2801-1401
E-mail: alyne_biomed @ hotmail.com
Universidade Federal do Delta do Parnaíbabrazil
Maria José dos Santos Soares
ORCID: https://orcid.org/0000-0002-4200-6350
Universidade Federal do Piauí, Brazil
E-mail: mrsapijf@gmail.com

\begin{abstract}
Quinones are a classic example of molecules isolated from natural products. These compounds are secondary metabolites produced by plants, fungi, bacteria, and insects and correspond to an interesting chemical class ubiquitously found in nature. The [rel-8 $\alpha$-Hydroxy-5-hydroxymethyl-2-methoxy- $8 \alpha, \beta$-methyl-7, 8, 8a, 9-tetahydro-1, 4-anthracenedione] [oncocalyxone A, onco-A] is a benzoquinone of dark red color isolated from the ethanolic extract of the species Cordia oncocalyx (Auxemma oncocalyx Allem). In this review, we aimed to investigate the main biological activities described for oncocalyxone A, as well as its isolation and characterization processes. For this review, the following descriptors were employed in multiple databases: medicinal plants, quinones, Auxemma oncocalyx, Cordia oncocalyx, biological activity. Besides, experimental papers published in international journals and with full text available were used as inclusion criteria. The biological activity profiles found for onco-A according to the literature were: antiproliferative/cytotoxic effects against SW1573 (alveolar cell carcinoma) and CCD922 (normal skin fibroblasts) cell lines; anti-inflammatory and analgesic potential; inhibitory effect on cell growth and DNA reactivity; antiplatelet activity; antitumor potential; anti-glycation agent; beneficial and/or toxic potential in goats and neuroinhibitory effect; antibacterial and antibiofilm activity. The substance has a broad spectrum of pharmacological applications, most of which are associated with its cytotoxic activity. The work also intends to compile the activities described in the literature, to understand how the molecule acts on the various targets, but, in some cases, more in-depth research is needed to elucidate the mechanisms of action.
\end{abstract}

Keywords: Quinones; Chemical properties; Isolated substance; Activity profile; Natural products; Metabolites secondary.

\section{Resumo}

As quinonas são um exemplo clássico de moléculas isoladas de produtos naturais. Estes são metabólitos secundários de plantas, fungos, bactérias e insetos, e correspondem a uma classe química interessante encontrada ubiquamente na natureza. $\mathrm{O}$ [rel-8 $\alpha$-hidroxi-5-hidroximetil-2-metoxi-8 $\alpha$, $\beta$-metil-7, 8, 8a, 9-tetahidro-1, 4-antracenediona] [oncocalixona A, onco-A] uma benzoquinona escura cor vermelha isolada do extrato etanólico da espécie Cordia oncocalyx (Auxemma oncocalyx Allem). Nesta revisão, propomos investigar as principais atividades biológicas descritas para a oncocalixona A, desde o seu isolamento até o processo de caracterização. Para esta revisão, os seguintes descritores foram empregados em múltiplas bases de dados: medicinal plants, quinones, Auxemma oncocalyx, Cordia oncocalyx, atividade biológica. Além disso, artigos experimentais 
publicados em periódicos internacionais e com texto completo disponível foram utilizados como critérios de inclusão. Os perfis de atividade biológica encontrados para o onco-A de acordo com a literatura foram: efeito antiproliferativo/citotóxico nas linhagens celulares SW1573 (carcinoma de células alveolares) e CCD922 (fibroblastos normais de pele); antiinflamatório e analgésico; efeito inibitório sobre o crescimento celular e reatividade do DNA; atividade antiplaquetária; potencial antitumoral; agente anti-glicação; potencial benéfico e / ou tóxico em caprinos e efeito neuroinibitório; atividade antibacteriana e antibiofilme. A substância possui um amplo espectro de aplicações farmacológicas, muitas das quais interligadas à atividade citotóxica. O trabalho busca, além de compilar as atividades descritas na literatura, entender como a molécula atua nos diversos alvos, mas, em alguns casos, pesquisas mais aprofundadas são necessárias para elucidar seus mecanismos de ação.

Palavras-chave: Quinonas; Propriedades químicas; Substância isolada; Perfil de atividade; Produtos naturais; Metabólitos secundários.

\section{Resumen}

Las quinonas son un ejemplo clásico de moléculas aisladas de productos naturales. Estos son metabolitos secundarios de plantas, hongos, bacterias e insectos, y corresponden a una clase química interesante que se encuentra ubicuamente en la naturaleza. La [rel-8 $\alpha$-hidroxi-5-hidroximetil-2-metoxi-8 $\alpha, \beta$-metil-7, 8, 8a, 9-tetahidro-1, 4-antracenodiona] [oncocalyxona A, onco-A] una benzoquinona de color oscuro color rojo aislado del extracto etanólico de la especie Cordia oncocalyx (Auxemma oncocalyx Allem). En esta revisión, proponemos investigar las principales actividades biológicas descritas para la oncocalyxona A, desde su aislamiento hasta el proceso de caracterización. Métodos. Para esta revisión, se emplearon los siguientes descriptores en múltiples bases de datos: plantas medicinales, quinonas, Auxemma oncocalyx, Cordia oncocalyx, actividad biológica. Además, se utilizaron como criterios de inclusión artículos experimentales publicados en revistas internacionales y con texto completo disponible. Resultados y discusión. Los perfiles de actividad biológica encontrados para onco-A según la literatura fueron: antiproliferativo/citotóxico en leucemia, tumor de pulmón [SW1573] y fibroblastos de piel normal [CCD922]; antiinflamatorio y analgésico; efecto inhibidor sobre el crecimiento celular y la reactividad del ADN; actividad antiplaquetaria; potencial antitumoral; agente anti-glicación; potencial beneficioso y / o tóxico en cabras y efecto neuroinhibidor; actividad antibacteriana y antibiofilm. La sustancia tiene un amplio espectro de aplicaciones farmacológicas, la mayoría de las cuales están interconectadas con la actividad citotóxica. El trabajo busca, además de recopilar las actividades descritas en la literatura, comprender cómo actúa la molécula sobre las distintas dianas, pero, en algunos casos, se necesita una investigación más profunda para dilucidar los mecanismos de acción de la misma.

Palabras clave: Quinonas; Propiedades químicas; Sustancia aislada; Perfil de actividad; Productos naturales; Metabolitos secundarios.

\section{Introduction}

The use of natural products is a growing reality, either in a practical context into popular folk medicine or in the study of their pharmacological properties by the scientific community. Medicinal plants are a clear example, once they are the object of interest of many studies that aim to explain the effects shown in their popular use (Sofowora; Ogunbodede \& Onayade, 2013). To study such compounds, it is essential to consider their ethnopharmacological characteristics, as well as the particularities of their use by the community, respecting the cultural aspects involved in the social context of a population (Oliveira et al., 2015; Naz et al., 2017).

Many species of medicinal plants are sources of bioactive constituents, which play a crucial role in studies involving the creation of new drugs addressed to several health problems worldwide (Sivasankar; Gayathri; Baskar; Krishnan \& Padian, 2017). Research on natural products has significantly contributed to the development of reliable and safe herbal medicines (Vieira; Sólon; Vieira \& Zárate, 2010). As abundant sources of several components, medicinal plants can synthesize multiple secondary metabolites, which can be extracted and then serve as raw materials for scientific research. Essential oils and various types of extracts can be cited as the most studied subjects due to their active pharmacological activities (Naveed et al., 2013).

In Brazil, studying the potential of medicinal plants is a reality for several research groups, both in preclinical studies and clinical trials. From this, researchers draw a large number of publications, demonstrating the scientific potential of the country (Dutra, Campos, Santos \& Calixto, 2016). Products obtained from medicinal plants have shown considerable effects on many health problems.

However, the lack of scientific evidence instigates the research for explaining the efficacy of these products in folk medicine (Lima et al., 2006). For example, quinones are biologically active compounds, widely found in nature, exhibiting 
various biological activities, including anticancer, antibacterial, anti-inflammatory, antioxidant, and antifungal (Sreelatha et al., 2014; Schaible et al., 2014; Oliveira et al., 2017; Yang et al., 2017).

Their irreversible contributions to electron transport in oxidation processes makes quinones molecules widely known. Their hydrophobic characteristics allow interactions with proteins and cell membranes (Madeo; Zubair \& Marianne, 2013). The structural variation in quinones directly implies their classification. When two adjacent carbonyls occur, the molecule is referred to as 1,2-quinones or ortho-quinones. If carbonyls are separated by two carbon atoms, the molecule is named 1,4quinone or para-quinones (De Lucas; Ferreira \& Netto-Ferreira, 2014).

Among the classes of quinones abundantly present in nature that serve as key molecules in the development of biologically active compounds, benzoquinones stand out for their scientifically proven effects (Abraham; Joshi; Pardasani \& Pardasani, 2011). Cordia oncocalyx, previously described as Auxemma oncocalyx, is an endemic species in northeastern Brazil. Its stem bark, which is popularly known as "white stick" and has an astringent effect, is used in folk medicine to treat cuts and wounds (Braga, 2001). Historically, A. oncocalyx was taxonomically reclassified to the genus to which it originally belonged, the genus Cordia, and for this reason, it is also known as Cordia oncocalyx (Gottschling \& Miller, 2006).

Early chemical investigations of the $C$. oncocalyx constituents allowed the isolation and characterization of oncocalyxone A [rel-8 $\alpha$-hydroxy-5-hydroxymethyl-2-methoxy-8a, $\beta$-methyl-7,8,8a, 9-thetahydro-1,4-anthracenedione] (oncoA), a dark red-colored benzoquinone obtained in large quantities from the ethanolic extract of this species (Pessoa; Lemos; Silveira \& Braz-Filho, 1993). From that, many studies have investigated and attributed pharmacological properties to this molecule. Therefore, other studies are necessary to highlight information in the literature about the biological activities of onco-A. This review aims to investigate the main biological activities described for the molecule, from its isolation and characterization to the present day.

\section{Methodology}

Bibliographic reviews allow the analysis of the most distinct and recent scientific publications available, contributing to the elaboration of a critical and detailed study. For this purpose, we consider the studies that follow the proposed theme or that serve as a theoretical and methodological basis for the development of the work. This type of investigation allows an update on the main discussions about the topic under study (Rother, 2007; Prodanov \& Freitas, 2013). In the present work, an integrative review was elaborated. This type of review represents an important academic contribution since it summarizes the results achieved in several studies in a systematic, orderly, and comprehensive manner (Ercole, Melo \& Alcoforado, 2014). Besides, integrative reviews have been conducted to assess the scientific contributions of other studies, so it is possible to carry out a critical analysis of the selected publications (Bezerra, Do Espírito Santo, Monteiro \& Muto, 2020; Sousa, Prete, Gomes, De Castro \& Ribeiro, 2021).

Given the objective of the study, the following descriptors were employed in the search for publications: quinones, chemical properties, isolated Substance, activity profile, natural products, metabolites secondary. The databases used for the search included PUBMED/NCBI, Science Direct, SCIELO, and Google Scholar. Our inclusion criteria consisted of experimental papers published in international journals, with full text available. These criteria aimed to restrict our findings to publications related to the theme of interest. Abstracts and publications without the evaluation of biological activities were excluded from the study. The data analysis and synthesis are succinctly and descriptively presented, which allows their observation, counting, and description, aiming to gather a set of information about the subject addressed. 


\section{Results}

\subsection{Quinones and their biological activities}

Structurally, quinones are conjugated cyclic molecules, originated from aromatic compounds by the conversion of hydrocarbon groups $(\mathrm{CH}=)$ into two carbonyl groups $(\mathrm{C}=\mathrm{O})$. They are considered responsible for the coloring and protection against pathogens (Madeo; Zubair \& Marianne, 2013; De Lucas; Ferreira \& Netto-Ferreira, 2014). The structural variation of quinones (Figure 1) implies their classification, which is based on the main aromatic system. Thus, a quinone is named benzoquinone when it is derived from a benzene; naphthoquinone when derived from naphthalene; anthraquinone if derived from an anthracene, and phenanthraquinones if derived from phenanthrene ring (De Lucas; Ferreira \& Netto-Ferreira, 2014; Sousa, Lopes \& De Andrade, 2016).

Figure 1. Classification of quinones according to the main aromatic system.

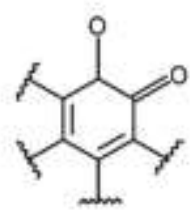

Benzoquinones

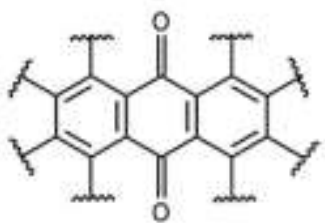

Anthraquinones

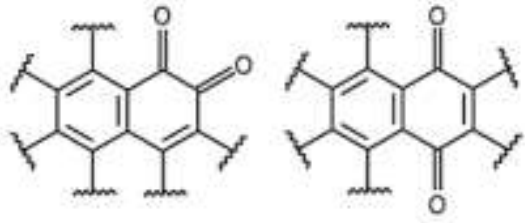

Naphthoquinones

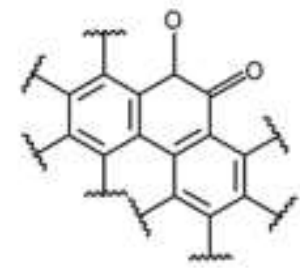

Phenanthraquinones

Source: Adapted from Sousa, Lopes \& De Andrade (2016).

Quinones are widely known due to their irreversible contributions in electron transport in oxidation-reduction processes (Madeo; Zubair \& Marianne, 2013; Sarewicz \& Osyczka, 2015). Such characteristic has been associated with important biological activities, demonstrating therapeutic and toxicological effects (Bayen et al., 2007). According to Monks \& Jones (2002), the activities presented by these substances are related to their structures. Also according to the authors, humans are exposed to this chemical class through three conditions, which include diet, drug use, and air pollution.

Fieser \& Fieser (1956) describe the first synthesis of a benzoquinone from an oxidation reaction between quinic acid, manganese dioxide, and sulfuric acid in the late 1830s. In the 1950s, mitomycin C, an isolated antibiotic, showed considerable antitumor effect. Later, in 1963, the isolation of daunorubicin, a glycosidic anthraquinone, addressed a significant antileukemic effect to this molecule. In 1969, doxorubicin was more effective than daunorubicin, showing effects against several types of tumors (O’brien, 1991).

Among the classes of quinones abundantly present in nature, serving as key molecules in the development of biologically active compounds, benzoquinones stand out for their scientifically proven effects (Abraham; Joshi; Pardasani \& Pardasani, 2011). The promising pharmacological and/or toxicological effects presented by benzoquinones and/or their derivatives make them targets of many studies. The reports of their use in the literature reflect this. Several findings reinforce the therapeutic potential of para-benzoquinones against several models of studies and scientific investigations. The study 
performed by Mostert, Petzer, and Petzer (2017), for example, demonstrated that molecules belonging to this class inhibited human monoamines oxidases (MOA).

Due to the microbial resistance issues, many studies currently focus on investigating the antibacterial and antifungal activity of benzoquinones and/or their derivatives. Jin \& Sato (2003), for example, identified the benzoquinone [2,5cyclohexadiene-1,4-dione] as the essential molecule responsible for the antibacterial activity presented by the aqueous extract obtained from the young shoots of the pear Pyrus spp. The authors came to this conclusion after isolation and identification studies of the molecule by nuclear magnetic resonance (nmr), mass spectrometry, and high-performance liquid chromatography (HPLC).

Drewes, Khan, Vuuren, and Viljoen (2005) described the isolation of a benzoquinone [2-methyl-6- [3-methyl-2butenyl] 1,4-benzoquinone] extracted from Gunnera perpensa. This benzoquinone displayed significant antibacterial activity against Staphylococcus epidermidis ATCC 2223, inhibiting the bacterial growth at a concentration of $9.8 \mu \mathrm{g} / \mathrm{ml}$. Other strains, including Staphylococcus aureus ATCC 6538, Enterococcus faecalis ATCC 29212, and Bacillus cereus ATCC 11778, were also sensitive to this compound. Recent studies have also determined the antimicrobial potential of other benzoquinones.

Pangal, Ahmed, and Shaikh (2013) studied molecules of the same class and demonstrated that these substances showed antibacterial activity against Staphylococcus aureus and Escherichia coli. Kurban et al. (2019) reported that modified benzoquinonic molecules inhibited the growth of the bacterial strains S. aureus 209-P, E. Coli B-906, and Mycobacterium luteum B-917. Growth inhibition was also observed against the fungal species Candida tenuis VKM Y-70 and Aspergillus niger F-1119.

\subsection{Oncocalixone A}

The Brazilian territory presents a diverse number of plant species, and many of these plants are used in folk medicine. In the state of Ceará, northeastern Brazil, Cordia oncocaclyx (Auxemma oncocalyx Allem) is an endemic species belonging to the boraginaceae family and is commonly applied in folk medicine [16, 17]. The $\beta$-sitosterol [3 $\beta$-o-d-glucopyranosyl sitosterol], its glycoside, as well as allantoin were isolated from its hydroalcoholic extract and were considered responsible for the biological activity reported by the popular use (Pessoa \& Lemos, 1997).

Chemical investigations from the ethanolic extract of $C$. oncocalyx allowed the isolation of seven terpenoid quinones. Among these, a dark red-colored quinone was obtained in large quantities and named oncocalixone A (Figure 2) [rel-8 $\alpha$ hydroxy-5-hydroxymethyl-2-methoxy-8a, $\beta$-methyl-7,8, 8a, 9-tetrahydro-1,4-anthracenedione].

Figura 2: 3D chemical structure of oncocalixone A.

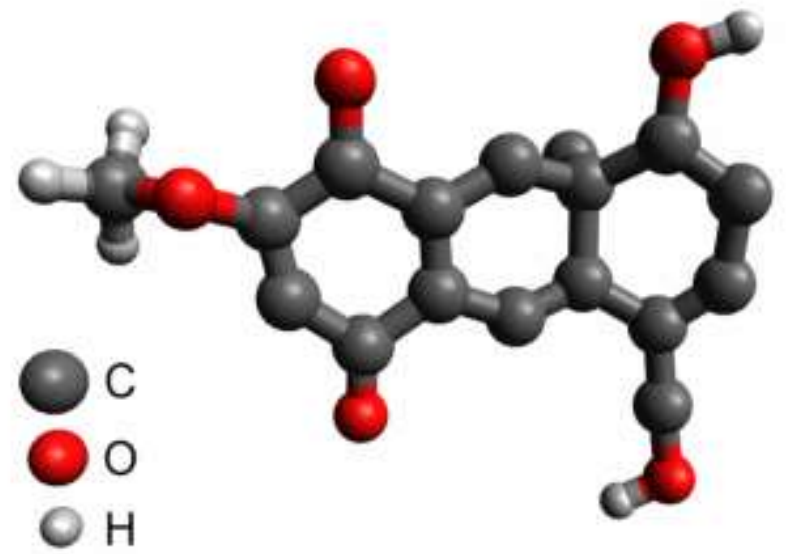

Source: Adapted from Pessoa et al. (1993). 


\subsection{Biological Activities of Oncocalixone A}

The studies published from 2000-2020 demonstrated that there are few biological properties (Table 1) described for Oncocalixone A. According to Table 1, it is possible to see that most activities comprise the cytotoxic potential of the molecule, both in cancerous and normal cells. As a proposal of this work, each biological activity profile listed in the table will be described and discussed below.

Table 1: Biological activities described in the literature for oncocalixone A.

\begin{tabular}{ccc}
\hline Author / year & Biological activity & Mechanism of action \\
\hline Pessoa et al., 2000 & $\begin{array}{c}\text { Antiproliferative / cytotoxic in leukemic, lung tumor } \\
\text { (SW1573) and normal skin fibroblasts (CCD922). }\end{array}$ & DNA damage \\
Costa-Lotufo et al., 2002 & Cytotoxic in sea urchin egg. & Membrane damage
\end{tabular}

Hepatoprotectant in a tetrachloride $(\mathrm{CCl} 4)$ induced toxicity

Ferreira et al., 2003

Pessoa et al., 2003

Ferreira et al., 2004

Pessoa et al., 2004

Ferreira et al., 2008

Costa et al., 2012

Barreto et al., 2013

Melo et al., 2015

Leiva-Revilla et al., 2016, 2017

Matos et al., 2017

Silva et al., 2020 model in mice.

Cytotoxic against human lymphocytes.

Anti-inflammatory (carrageenan-induced paw edema model) and analgesic (acetic acid-induced abdominal contortion) in rats.

Antinociceptive.

Antiproliferative against leukemic cell line.

Antiaggregant evaluated by in vitro models, induced by adenosine diphosphate (ADP), collagen, arachidonic acid

(AA), thrombin, and ristocetin, in platelet rich plasma (PRP).

DNA interleaving, employing an electrochemical model with DNA biosensors.

Antitumor activity

Antiglycation in an in vitro model of glucose and fructoseinduced glycation.

Cytotoxic follicle in goat follicles.

Neuroinhibitory effect

Antimicrobial and antibiofilm activity
Free radical inhibition and lipid peroxidation

Inhibition of G1/S phase DNA synthesis

Peripheral action independent of opioid system

DNA damage

Increased cGMP levels, regardless of NO participation. GP Ib $\alpha$ glycoprotein blockade, which plays an active role in the platelet aggregation process.

Interaction with guanine and adenine bases

ROS inhibition

Morphological and numerical alteration of the follicles

Involvement of presynaptic histamine and noradrenaline inhibitor receptors.

Morphological changes, independent of oxidative stress 


\subsection{Onco-A antiproliferative/cytotoxic effect}

The effects of onco-A have been described in literature using both in vitro and in vivo models. One of the first reported studies was performed by Pessoa et al. (2000), who evaluated the antiproliferative/cytotoxic effect of different plant compounds from northeastern Brazil. The authors identified four of these compounds and reported their potential to inhibit the proliferation of different human cell lines, which included the cancer cell lines CEM (acute lymphoblastic leukemia) and SW1573 (alveolar cell carcinoma), as well as the normal skin fibroblasts cell line CCD922. The study showed one of the first potent biological activities of this metabolite.

Costa-Lotufo, Ferreira, Lemos, Viana \& Cunha (2002) used the sea urchin egg development model to evaluate the effect of the quinone fraction obtained from C. oncocalyx on the cell division and embryonic development of this species. The evaluation of the cleavage parameters and blastula form revealed that the compound was toxic, inhibiting around $50 \%$ of the development of sea urchin eggs, depending on the concentration.

Some characteristics, such as the induction of abnormalities in the third cleavage and the destruction of the embryos through membrane damage, were attributed to the presence of onco-A once it was the main constituent of the fraction used in the study. Considering the antitumor potential described previously, conferred by its antimitotic activity, Costa-Lotufo et al. (2002) also investigated the antitumor potential of onco-A once it caused embryonic destruction at concentrations similar to those tested against cancer cells. However, the authors emphasized the need to use antimitotic quinones with lower cytotoxicity.

Based on the antitumor activity demonstrated and considering the use of $C$. oncocalyx in folk medicine, the genotoxic effects of onco-A compared to its cytotoxic activity was also analyzed by in vitro assays against human lymphocytes (Pessoa et al., 2003). The cells were treated with $0.5 \mu \mathrm{g} / \mathrm{mL}$ of onco-A at G1, G1/S, and S phases of the cell cycle. The results obtained by analyzing the mitotic index parameter known as the number of dividing cells showed similar cytotoxicity with the control used, with minor toxic effect in the S phase. With the results obtained, the authors suggested an inhibition of the DNA synthesis, especially in the G1/S transition phase. Besides, onco-A did not induce expressive chromosomal aberrations in the tested cell line, demonstrating absence of genotoxicity. The information obtained by Pessoa et al. (2003) reinforce the therapeutic application of this compound.

\subsection{Hepatoprotective and antioxidant effects}

Ferreira et al. (2003) evaluated the hepatoprotective effect of onco-A by measuring plasma GOT (glutamate-oxalatetransaminase) and GPT (glutamate-pyruvate-transaminase) in a model of carbon tetrachloride-induced toxicity $\left(\mathrm{CCl}_{4}\right)$ in mice. The results showed that intraperitoneal administration of onco-A $(10 \mathrm{mg} / \mathrm{kg})$ reversed the enzyme levels in the studied model. The most significant inhibition was observed for GPT levels, known as a specific parameter for liver lesion analysis. The effect observed was correlated with the antioxidant property of the studied quinone, from free radical inhibition and lipid peroxidation.

\subsection{Anti-inflammatory and analgesic potentials of onco-A}

When studying the quinone fraction obtained from C. oncacalyx, Ferreira et al. (2004) demonstrated the antiinflammatory and analgesic potential of this compound. In the study, the authors used doses of 10 and $30 \mathrm{mg} / \mathrm{kg}$ with intraperitoneal (i.p.) administration in rats. The results revealed that the fraction significantly reduced carrageenan-induced paw edema by up to $57 \%$ and $60 \%$ in the third hour, respectively. In dextran-induced paw edema, the treatment with $30 \mathrm{mg} / \mathrm{kg}$ of the substance reduced the inflammation within the first hour (26.7\% inhibition). In the acetic acid-induced abdominal 
writhing test, doses of 1 and $5 \mathrm{mg} / \mathrm{kg}$ of the compound inhibited, respectively, $26 \%$ and $60 \%$ of the writhing in a dosedependent manner.

The same study also investigated the effect of the compound on formalin-induced nociception in two distinct phases, known as neurogenic phase and inflammatory phase. The intraperitoneal administration of 5, 10, and $30 \mathrm{mg} / \mathrm{kg}$ resulted in the reduction of $27 \%, 52 \%$, and $67 \%$ of the paw licking time, respectively, in the second phase, suggesting a response involved with the inflammatory process. In contrast, there was no evidence of changes in the effect presented by the quinone fraction in the presence of the antagonist (naloxone) when compared to the effect of the fraction alone, which demonstrates the nonparticipation of the opioid system (Ferreira et al., 2004).

Moreover, the same doses abovementioned were also used in the hot plate model, and no effect was observed. Since this is a model with higher brain function involvement, the authors suggested that the antinociceptive activity of the quinone fraction represented an independent peripheral action and that the effects observed in different study models were probably associated with the presence of onco-a, the main component of the studied fraction (Ferreira et al., 2004).

\subsection{Inhibitory effect on cell growth and DNA reactivity}

Pessoa et al. (2004) investigated the effect of three onco-A derivatives, modified by chlorination and acetylation reactions, on cell growth and DNA reactivity. The results showed that two out of the three modified molecules tested were less active against the leukemic cell line when compared to unmodified onco-A. However, the authors observed that both modified and natural onco-A molecules were able to damage DNA at a concentration of $5 \mu \mathrm{g} / \mathrm{mL}$.

This interaction with DNA was also reported in the study performed by Costa et al. (2012), who used an electrochemical model with DNA biosensors. This model works as a screening alternative for in vitro molecular interaction studies. Using a single-stranded DNA (ssDNA), the authors observed that onco-A interacted with the bases Guanine and Adenine. This effect was evidenced by a decrease in the oxidation peaks of these bases. Besides, nucleotide analysis (polyadenyl acid - Poly A) allowed the authors to determine the influence of the sugar-phosphate moiety on oxidation. From this, it was shown that the interaction between onco-A and Poly A occurs with high intensity, which evidences its connection with the DNA molecule.

\subsection{Antiplatelet Activity}

Ferreira et al. (1999) demonstrated the antiplatelet activity of the aqueous fraction obtained from C. oncocalyx ethanolic extract. Additionally, the same authors also investigated the mechanism involved in this anti-aggregating activity. Since onco-A is the major constituent of the previously studied fraction, its effect has been evaluated by in vitro models against platelet aggregation induced by different agonists (Ferreira et al., 2008).

The study showed that onco-A inhibited platelet aggregation, with IC50 of 85, 122, 159, 161, and $169 \mu \mathrm{M}$ for thrombin, ADP (adenosine diphosphate), AA (arachidonic acid), collagen, and ristocetin models, respectively, using plateletrich plasma (PRP). In the AA induction model, onco-A did not promote any functional platelet damage, inhibiting platelet aggregation by $96 \%$ at a concentration of $256 \mu \mathrm{M}$.

Besides, collagen-induced aggregation was used to investigate the involvement of thromboxane A2 (TXA2) in oncoA anti-aggregating activity once it is a powerful platelet activator. The results showed that when TXA2 was blocked by aspirin, the molecule activity remained at the four concentrations tested $(32,64,128$ and $256 \mu \mathrm{M})$, suggesting the participation of other mechanisms in this effect (Ferreira et al., 2008). 
Sodium nitroprusside (SNP), which is known as an important antiplatelet agent and NO (nitric oxide) donor, targets the soluble guanylate cyclase (sGC) enzyme. The involvement of this enzyme in the activity promoted by onco-A was evaluated by the stimulation of ADP-mediated platelet aggregation. The results showed that the effect of SNP was blocked by $82 \%$ by specifically blocking NO binding to the sGC target site with ODQ [oxadiazolo (4,3-a) quinoxalin-1-one], its major inhibitor. The role of phosphodiesterase-5 was also evaluated by the action of its inhibitor, sildenafil (Ferreira et al., 2008).

As noted earlier, Ferreira et al. (2008) also showed that sildenafil did not inhibit platelet aggregation but potentiated the anti-aggregating effect of SNP. The authors observed a similar effect for onco-A once the association of the molecule with SNP significantly inhibited platelet aggregation. Onco-A binding to specific platelet surface receptors was investigated by flow cytometry using monoclonal antibodies against CD42b (GP Ib $\alpha$ of GP Ib/V/IX complex, von Willebrand receptor), CD41a (GP IIb of complex IIbIIIa, a fibrinogen receptor), and CD62P (P-selectin). Upon activation by collagen, $\alpha 2 \mathrm{~b} 1$ integrin, its main receptor, was labeled with antibodies against CD49b and CD29.

This result demonstrated that the molecule was able to interact with GP Ib $\alpha$, inducing a concentration-dependent inhibition of platelet aggregation in antibody binding. The GP Ib $\alpha$ subunit is involved with platelet adhesion and, in the thrombin and ristocetin induction model, it represents the major portion involved with the activation of its respective receptor. Binding of onco-A to this glycoprotein, thereby interfering with antibody binding, suggested a potent inhibition of platelet aggregation attributed to this secondary metabolite.

\subsection{Nanoformulation and antitumor potential}

Establishing an association with the antitumor potential of this molecule and the development of nanostructured systems, Barreto et al. (2013) reported the synthesis of an iron oxide $\left[\mathrm{Fe}_{3} \mathrm{O}_{4}\right]$ nanoparticles system for storing and releasing onco-A, targeting cancer therapy. The release assay was performed by the UV-vis method and highlighted a fast release of the compound in the first 10 hours. Simulating the physiological condition with $\mathrm{pH} 7.4$ and temperature of $37^{\circ} \mathrm{C}$, the authors found the maximum release of onco-A, reaching about $60 \%$ after 72 hours.

\subsection{Anti-glycation agent}

The anti-glycation activity of Onco-A was proposed by Melo, Santos, Lemos, Goulart \& Santana (2015). The result of the glycation process is the irreversible formation of advanced glycation end products (AGE). These products interact with other proteins, leading to damage and degradation actions, characterized by proteins with altered structures or functions.

The anti-glycation potential of the molecule was investigated in an in vitro model of glucose- and fructose-induced glycation. Onco-A significantly inhibited AGE formation, in a concentration-dependent manner, with an IC50 of $87.88 \pm 3.08$ $\mu \mathrm{M}$ when compared to the control (aminoguanidine).

\subsection{Survival, growth, apoptosis, and proliferation with goat preantral follicle culture}

Considering the importance of determining the beneficial and/or toxic potential of new compounds, Leiva-Revilla et al. (2016) used an in vitro model with goat preantral follicle culture to evaluate parameters as survival, growth and development, as well as apoptosis and follicular proliferation to investigate the effects of the quinone fraction with onco-A as main constituent. The method is applicable because it precedes experimental protocols involving animals and humans.

From the observed parameters, it was found that both the fraction and its isolated compound were able to affect the development of goat preantral follicles, in a concentration-dependent manner. Besides, onco-A demonstrated less harmful effect when compared to the standard control of antitumor therapy, doxorubicin (Leiva-Revilla et al., 2016). 
From these findings and following the same reasoning in the use of this study model, another study performed by Leiva-Revilla et al. (2017) evaluated the effects of the same compounds on the culture of isolated secondary goat follicles. The viability and nuclear maturation of oocytes obtained from antral follicles were also determined. These parameters were evaluated through treatments with C. oncocalyx fraction, onco-A, doxorubicin, and controls (untreated group).

Under the established conditions, it was observed that the quinone fraction and its isolated molecule were not toxic and did not change the in vitro maturation rates of the culture used in this assay, corroborating with the results obtained previously. However, both compounds impaired oocyte viability after in vivo maturation. Also, as shown above, onco-A was less harmful when compared to the positive control, secondary follicle survival, and to oocytes tested (Leiva-Revilla et al., 2017).

\subsection{Neuroinhibitory effect}

Matos et al. (2017) investigated the neuroinhibitory effect of different compounds obtained from A. oncocalyx (C. oncocalyx), among them onco-A. The molecule inhibited neurogenic contractions and the authors found that the mechanism of action was related to a presynaptic inhibition involving the co-release of histamine and norepinephrine, as well as the inhibitory receptors of these neurotransmitters.

\subsection{Antimicrobial and antibiofilm activity}

Antibacterial and antibiofilm activity was assessed by Silva et al. (2020). Onco-A showed antibacterial effect against different Gram-positive bacterial strains and two Gram negative species, including clinical specimens. The strain Staphylococcus epidermidis ATCC 12228 was more sensitive to the molecule, with MIC $=9.43 \mu \mathrm{g} / \mathrm{mL}$. Besides, Methicillin resistant strains were also sensitive to the compound. The molecule inhibited $\sim 70 \%$ of the initial biofilm formation of the Staphylococcus aureus MED 55 strain (resistant clinical specimen). Onco-A did not show antifungal activity in the concentrations used in the cited study, however it was compatible with human erythrocytes within the concentrations that inhibited bacterial growth.

\section{Discussion}

Quinones are a classic example of molecules isolated from natural products. These are secondary metabolites produced by plants, fungi, bacteria, and insects, and they correspond to an interesting chemical class found ubiquitously in nature. The participation of these compounds in the development of their precursors is associated with the electron transport chain in cellular respiration and photosynthesis (Monks; Hanzlik; Cohen; Ross \& Graham, 1992). Historically, these molecules have sparked interest in the chemical and pharmaceutical fields. The isolation and identification of these pigments with biological activities has served as the basis for the exploration of many natural quinones for dyes and medicines conception (Furusaki et al., 1972; Bayen et al., 2007).

According to Madeo, Zubair \& Marianne (2013), the hydrophobic characteristics of quinones allow interactions with proteins and cell membranes. To become stable and biologically active they need to be reduced. In this case, they work as oneand/or two-electron [redox cycle] -supporting molecules, resulting in the corresponding radical anion or diium formation in situ (Salmon-Chemin et al., 2001). These, on the other hand, have important participation in cellular processes and can also damage the DNA molecule and proteins, thereby controlling the biological activities presented (O'brien, 1991).

Among the quinones found in $C$. oncocalyx extract, oncocalixone A was considered responsible for the heartwood color of the plant stem and was classified as a para-benzoquinone (Pessoa; Lemos; Silveira \& Braz-Filho, 1993; Pessoa; 
Lemos; Carvalho; Braz-Filho, 1995). The possible mechanisms of action related to cytotoxicity shown in Table 1 may include DNA damage and inhibition of DNA synthesis. However, few studies report the pathways involved with the effects of the molecule, thus, further studies are needed for this elucidation.

Based on the cell growth inhibitory effect and DNA damage, the literature found that the original quinone [onco-A] displays better activity when compared to the modified molecules. In the study, the authors concluded that this effect was associated with a decrease in DNA intercalation, which led to less damage to deoxyribonucleic acid. This result could be explained by the presence of the polycyclic planar aromatic ring in the structure of onco-A. This complex is considered an important feature for intercalating compounds. Modifications in specific positions of the molecule could also be responsible for inhibiting the DNA binding (Pessoa et al., 2004).

The evaluation of the mechanisms involved in the antiplatelet activity of onco-A showed a correlation with increased cGMP levels, an independent effect of NO participation, and a blockade of the GP Ib $\alpha$, which has an active participation in the platelet aggregation process. The findings made onco-A a strong candidate for the development of antithrombotic drugs (Ferreira et al., 2008). Besides, the results about nanoformulation highlighted the potential of the nanosystem developed as an alternative to cancer therapy (Barreto et al., 2013).

The anti-glycation effect of onco-A was attributed its antioxidant potential of the molecule once the inhibition of ROS [reactive oxygen species] is associated with the mechanisms involved in the activity of the anti-glycation agent. The findings reinforced the viability of this molecule in the treatment of complications associated with AGE excess (Melo, Santos, Lemos, Goulart \& Santana, 2015). With this, the biological potential presented by quinones is evident, especially benzoquinones, which are the focus of many studies. Molecules of this class, originally extracted from natural products, and those subjected to chemical modifications, have shown significant pharmacological potential, which make them promising substances in preclinical studies.

The evaluation of the antimicrobial action demonstrated that onco-A promotes structural changes in the morphology of prokaryotic cells, and that its effect in inhibiting bacterial growth is independent of oxidative stress (Silva et al., 2020).

\section{Conclusion}

Oncocalyxone-A has a wide spectrum of pharmacological applications, most associated with its cytotoxic profile, involving cancer and normal cells. As previously observed, the work also aims to compile the activities described in the literature, to understand how the molecule acts on the various targets, but, in some cases, more indepth research is needed to elucidate the mechanisms of action. Despite the activities previously reported for oncoA, there are few reports of antiparasitic and antifungal activity, highlighting the importance of future trials to elucidate such potentials since other quinones have already demonstrated such actions.

Besides, it is emphasized that conducting future investigations may significantly contribute to the monitoring of studies with Oncocalixone A, making it possible to assess its pharmacological and biological potentials.

\section{References}

Abraham, I., Joshi, R., Pardasani, P., \& Pardasani, R. T. (2011). Recent advances in 1, 4-benzoquinone chemistry. Journal of the Brazilian Chemical Society, 22(3), 385-421. https://www.scielo.br/scielo.php?pid=S0103-50532011000300002\&script=sci_arttext. 
Barreto, A. C., Santiago, V. R., Freire, R. M., Mazzetto, S. E., Denardin, J. C., Mele, G., ... \& Fechine, P. (2013). Magnetic nanosystem for cancer therapy using oncocalyxone A, an antitomour secondary metabolite isolated from a Brazilian plant. International journal of molecular sciences, 14(9), 18269-18283. https://www.mdpi.com/1422-0067/14/9/18269.

Bayen, S., Barooah, N., Sarma, R. J., Sen, T. K., Karmakar, A., \& Baruah, J. B. (2007). Synthesis, structure and electrochemical properties of 2, 5-bis (alkyl/arylamino) 1, 4-benzoquinones and 2-arylamino-1, 4-naphthoquinones. Dyes and Pigments, 75(3), 770-775. https://www.sciencedirect.com/science/article/pii/S0143720806003172.

Bezerra, D. R. C., do Espírito Santo, F. H., Monteiro, J. K. D. M. F., \& Muto, T. S. (2020). Os vulneráveis no período do COVID-19: uma revisão integrativa de literatura. Research, Society and Development, 9(10), e4699108860-e4699108860. https://rsdjournal.org/index.php/rsd/article/view/8860/7816.

Braga, R. (2001). Plantas do Nordeste: especialmente do Ceará. Fundação Guimaraes Duque. https://ci.nii.ac.jp/naid/10006226843/.

Costa, C. D. O., Costa, E. D. O., Ferreira, F. D. R., Viana, L. D. S., Silva, L. V. D., Silva, F. D. A., ... \& Goulart, M. O. (2012). Oncocalyxone A: electrochemical, spectroscopic investigation and studies of its interaction with DNA, nucleobases and N-acetylcysteine. Journal of the Brazilian Chemical Society, 23(6), 1174-1185. https://www.scielo.br/scielo.php?pid=S0103-50532012000600024\&script=sci_arttext\&tlng=es

Costa-Lotufo, L. V., Ferreira, M. A. D., Lemos, T. L. G., Pessoa, O. D. L., Viana, G. S. B., \& Cunha, G. M. A. (2002). Toxicity to sea urchin egg development of the quinone fraction obtained from Auxemma oncocalyx. Brazilian journal of medical and biological research, 35(8), 927-930. https://www.scielo.br/scielo.php?pid=S0100-879X2002000800010\&script=sci_arttext.

Da Silva, R. E., Ribeiro, F. D. O. S., de Carvalho, A. M. A., Daboit, T. C., Marinho-Filho, J. D. B., Matos, T. S., ... \& dos Santos Soares, M. J. (2020). Antimicrobial and antibiofilm activity of the benzoquinone oncocalyxone A. Microbial Pathogenesis, 149, 104513. https://www.researchgate.net/profile/Rai_Silva3/publication/344331196_Antimicrobial_and_antibiofilm_activity_of_the_benzoquinone_oncocalyxone_A/link s/60078310299bf14088aa59d0/Antimicrobial-and-antibiofilm-activity-of-the-benzoquinone-oncocalyxone-A.pdf.

De Lima, M. R. F., de Souza Luna, J., Dos Santos, A. F., De Andrade, M. C. C., Sant'Ana, A. E. G., Genet, J. P., ... \& Moreau, N. (2006). Anti-bacterial activity of some Brazilian medicinal plants. Journal of 137-147. https://www.sciencedirect.com/science/article/abs/pii/S0378874105007452.

De Lucas, N. C., Ferreira, A. B., \& Netto-Ferreira, J. C. (2015). Fotoquímica de naftoquinonas. Revista Virtual de Química, 7(1), 403-463. http://rvqsub.sbq.org.br/index.php/rvq/article/view/997.

De Oliveira, A. S., Brighente, I. M., Lund, R. G., Llanes, L. C., Nunes, R. J., Bretanha, L. C., ... \& Ribeiro, J. S. (2017). Antioxidant and antifungal activity of naphthoquinones dimeric derived from lawsone. Journal of Biosciences and Medicines, 5(2), 39-48. https://www.scirp.org/journal/paperinformation.aspx?paperid=74230

Drewes, F. S.E., Khan, S.F. Vuuren, A.M. Viljoen, Simple 1,4-benzoquinones with antibacterial activity from stems and leaves of Gunnera perpensa. Phytochemistry, 66 (2005) 1812-1816. https://www.sciencedirect.com/science/article/abs/pii/S0031942205002517.

Dutra, R. C., Campos, M. M., Santos, A. R., \& Calixto, J. B. (2016). Medicinal plants in Brazil: Pharmacological studies, drug discovery, challenges and perspectives. Pharmacological research, 112, 4-29. https://www.sciencedirect.com/science/article/abs/pii/S1043661816000232

Ercole, F. F., Melo, L. S. D., \& Alcoforado, C. L. G. C. (2014). Revisão integrativa versus revisão sistemática. Revista Mineira de Enfermagem, 18(1), 9-12. http://www.reme.org.br/artigo/detalhes/904.

Ferreira, M. A. D., Do Nascimento, N. R. F., De Sousa, C. M., Pessoa, O. D. L., De Lemos, T. L. G., Ventura, J. S., ... \& Chudzinski-Tavassi, A. M. (2008). Oncocalyxone A inhibits human platelet aggregation by increasing cGMP and by binding to GP Ib $\alpha$ glycoprotein. British journal of pharmacology, 154(6), 1216-1224. https://bpspubs.onlinelibrary.wiley.com/doi/full/10.1038/bjp.2008.199.

Ferreira, M. A. D., Nunes, O. D. R. H., Leal, L. K. A. M., Pessoa, O. D. L., De Lemos, T. L. G., \& de Barros Viana, G. S. (2003). Antioxidant Effects in the Quinone Fraction from Auxemma oncocalyx Taub. Biological and Pharmaceutical Bulletin, 26(5), 595-599. https://www.jstage.jst.go.jp/article/bpb/26/5/26_5_595/_article/-char/ja/.

Ferreira, M. A. D., Nunes, O. D., Fontenele, J. B., Pessoa, O. D., Lemos, T. L., \& Viana, G. S. (2004). Analgesic and anti-inflammatory activities of a fraction rich in oncocalyxone A isolated from Auxemma oncocalyx. Phytomedicine, 11(4), 322. https://www.sciencedirect.com/science/article/abs/pii/S0944711304703347.

Ferreira, M. A., Nunes, O. D., Fujimura, A. H., Pessoa, O. D., Lemos, T. L., \& Viana, G. S. (1999). Inhibition of platelet activation by quinones isolated from Auxemma oncocalyx Taub. Research communications in molecular pathology and pharmacology, 106(1-2), 97-107. https://europepmc.org/article/med/11127812.

Furusaki, A., Matsui, M., Watanabé, T., Ōmura, S., Nakagawa, A., \& Hata, T. (1972). The Crystal and Molecular Structure of Kinamycin C p-Bromobenzoate. Israel Journal of Chemistry, 10(2), 173-187. https://onlinelibrary.wiley.com/doi/abs/10.1002/ijch.197200023.

Gottschling, M., \& Miller, J. S. (2006). Clarification of the taxonomic position of Auxemma, Patagonula, and Saccellium (Cordiaceae, Boraginales). Systematic Botany, 31(2), 361-367. https://www.ingentaconnect.com/content/aspt/sb/2006/00000031/00000002/art00014.

Jin, S., \& Sato, N. (2003). Benzoquinone, the substance essential for antibacterial activity in aqueous extracts from succulent young shoots of the pear Pyrus spp. Phytochemistry, 62(1), 101-107. https://www.sciencedirect.com/science/article/abs/pii/S0031942202004442.

Kurban, S., Deniz, N. G., Sayil, C., Ozyurek, M., Guclu, K., Stasevych, M., ... \& Novikov, V. (2019). Synthesis, antimicrobial properties, and inhibition of catalase activity of 1, 4-naphtho-and benzoquinone derivatives containing N-, S-, O-substituted. Heteroatom Chemistry, 2019. https://www.hindawi.com/journals/htrc/2019/1658417/. 
Leiva-Revilla, J., De los Reyes Cadenas, J., Vieira, L. A., Campello, C. C., de Holanda Celestino, J. J., Pessoa, O. D. L., ... \& Maside, C. (2017). Toxicity effect of Auxemma oncocalyx fraction and its active principle oncocalyxone A on in vitro culture of caprine secondary follicles and in vitro oocyte maturation. Semina: Ciências Agrárias, 38(3), 1361-1373. https://www.redalyc.org/pdf/4457/445751259023.pdf.

Leiva-Revilla, J., Lima, L. F., Castro, S. V., Campello, C. C., Araújo, V. R., de Hollanda Celestino, J. J., ... \& Figueiredo, J. R. (2016). Fraction of Auxemma oncocalyx and Oncocalyxone A affects the in vitro survival and development of caprine preantral follicles enclosed in ovarian cortical tissue. Complementary Medicine Research, 23(5), 307-313. https://www.karger.com/Article/Abstract/450719.

Madeo, J., Zubair, A., \& Marianne, F. (2013). A review on the role of quinones in renal disorders. Springerplus, 2(1), 1-8. https://link.springer.com/article/10.1186/2193-1801-2-139

Mandell, L. (1956). The mechanism of the Wettstein-Oppenauer oxidation. Journal of the American Chemical Society, 78(13), 3199-3201. https://pubs.acs.org/doi/pdf/10.1021/ja01594a061.

Matos, T. S., Silva, A. K. O., Quintela, A. L., das Chagas Pinto, L. F., Canuto, K. M., Braz-Filho, R., ... \& Pessoa, O. D. L. (2017). Neuroinhibitory meroterpenoid compounds from Cordia oncocalyx. Fitoterapia, 123, 65-72. https://www.sciencedirect.com/science/article/abs/pii/S0367326X17311115.

Melo, I. S. V. D., Santos, A. F. D., Lemos, T. L. G. D., Goulart, M. O. F., \& Santana, A. E. G. (2015). Oncocalyxone A functions as an anti-glycation agent in vitro. Plos one, 10(6), e0131222. https://journals.plos.org/plosone/article?id=10.1371/journal.pone.0131222.

Monks, T. J., \& Jones, D. C. (2002). The metabolism and toxicity of quinones, quinonimines, quinone methides, and quinone-thioethers. Current drug metabolism, 3(4), 425-438. https://www.ingentaconnect.com/content/ben/cdm/2002/00000003/00000004/art00005.

Monks, T. J., Hanzlik, R. P., Cohen, G. M., Ross, D., \& Graham, D. G. (1992). Quinone chemistry and toxicity. Toxicology and applied pharmacology, 112(1), 2-16. https://www.sciencedirect.com/science/article/abs/pii/0041008X9290273U.

Mostert, S., Petzer, A., \& Petzer, J. P. (2017). The evaluation of 1, 4-benzoquinones as inhibitors of human monoamine oxidase. European journal of medicinal chemistry, 135, 196-203. https://www.sciencedirect.com/science/article/abs/pii/S0223523417303215.

Naveed, R., Hussain, I., Tawab, A., Tariq, M., Rahman, M., Hameed, S., Mahmood, M.S., Siddique, A. B., Iqbal., M. Antimicrobial activity of the bioactive components of essential oils from Pakistani spices against Salmonella and other multi-drug resistant bacteria. BMC Complementary and Alternative Medicine, 13 (1) (2013) 265. https://link.springer.com/article/10.1186/1472-6882-13-265.

Naz, R., Ayub, H., Nawaz, S., Islam, Z. U., Yasmin, T., Bano, A., ... \& Roberts, T. H. (2017). Antimicrobial activity, toxicity and anti-inflammatory potential of methanolic extracts of four ethnomedicinal plant species from Punjab, Pakistan. BMC complementary and alternative medicine, 17(1), 1-13. https://link.springer.com/article/10.1186/s12906-017-1815-z.

Oliveira, D. R., Krettli, A. U., Aguiar, A. C. C., Leitão, G. G., Vieira, M. N., Martins, K. S., \& Leitão, S. G. (2015). Ethnopharmacological evaluation of medicinal plants used against malaria by quilombola communities from Oriximiná, Brazil. Journal of ethnopharmacology, 173, 424-434. https://www.sciencedirect.com/science/article/pii/S0378874115300520.

O'brien, P.J. Molecular Mechanisms of Quinone Cytotoxicity. Chemico-Biological interactions, $80 \quad(1991) \quad 1-41$. https://www.sciencedirect.com/science/article/abs/pii/0009279791900297.

Pangal, A., Ahmed, K., \& Shaikh, S. (2013). Synthesis, characterization and study of antimicrobial activity of 2, 6-Ditertiary Butyl-1, 4-benzoquinone hydrazones. International Research Journal of Pharmacy, 4(8), 172-176.

Pessoa, C., Lemos, T. L., Pessoa, O. D., Moraes, M. O., Vasconcellos, D., Costa-Lotufo, L. V., \& Leyva, A. (2004). Cytotoxicity of derivatives of oncocalyxone A from Auxemma oncocalyx Taub. Arkivoc, 6, 89-94. https://www.researchgate.net/profile/Leticia-CostaLotufo/publication/228865358_Cytotoxicity_of_derivatives_of_oncocalyxone_A_from_Auxemma_oncocalyx_Taub/links/0c960534d188f966d30000000/Cytot oxicity-of-derivatives-of-oncocalyxone-A-from-Auxemma-oncocalyx-Taub.pdf.

Pessoa, C., Silveira, E. R., Lemos, T. L. G., Wetmore, L. A., Moraes, M. O., \& Leyva, A. (2000). Antiproliferative effects of compounds derived from plants of Northeast Brazil. Phytotherapy Research, 14(3), 187-191. https://onlinelibrary.wiley.com/doi/abs/10.1002/(SICI)1099-1573(200005)14:3\%3C187::AIDPTR572\%3E3.0.CO;2-I.

Pessoa, C., Vieira, F. M. A. C., Lemos, T. G., Moraes, M. O., Lima, P. D. L., Rabenhorst, S. H. B., ... \& Burbano, R. R. (2003). Oncocalyxone A from Auxemma oncocalyx lacks genotoxic activity in phytohemagglutinin-stimulated lymphocytes. Teratogenesis, carcinogenesis, and mutagenesis, 23(S1), 215220. https://onlinelibrary.wiley.com/doi/abs/10.1002/tcm.10075.

Pessoa, O. D. L., \& Lemos, T. L. G. (1997). Allantoin and fatty acid composition in Auxemma oncocalyx. Revista Brasileira de Farmácia, 78, 9-10.

Pessoa, O. D., De Lemos, T. L., De Carvalho, M. G., \& Braz-Filho, R. (1995). Cordiachromes from Auxemma oncocalyx. Phytochemistry, 40(6), 1777-1786. https://www.sciencedirect.com/science/article/abs/pii/003194229500397P.

Pessoa, O. D., Lemos, T. L., Silveira, E. R., \& Raimundo, B. F. (1993). Novel cordiachromes isolated from Auxemma oncocalyx. Natural Product Letters, 2(2), 145-150. https://www.tandfonline.com/doi/abs/10.1080/10575639308043799.

Prodanov, C. C., \& de Freitas, E. C. (2013). Metodologia do trabalho científico: métodos e técnicas da pesquisa e do trabalho acadêmico-2a Edição. Editora Feevale.

Rother, E. T. (2007). Revisão sistemática X revisão narrativa. Acta paulista de enfermagem, 20(2), v-vi. https://www.scielo.br/scielo.php?pid=S010321002007000200001\&script=sci_arttext\&tlng=pt. 
Research, Society and Development, v. 10, n. 4, e57810414343, 2021

(CC BY 4.0) | ISSN 2525-3409 | DOI: http://dx.doi.org/10.33448/rsd-v10i4.14343

Salmon-Chemin, L., Buisine, E., Yardley, V., Kohler, S., Debreu, M. A., Landry, V., ... \& Davioud-Charvet, E. (2001). 2-and 3-Substituted 1, 4Naphthoquinone derivatives as subversive substrates of trypanothione reductase and lipoamide dehydrogenase from Trypanosoma cruzi: Synthesis and correlation between redox cycling activities and in vitro cytotoxicity. Journal of medicinal chemistry, 44(4), 548-565. https://pubs.acs.org/doi/abs/10.1021/jm0010791.

Sarewicz, M., \& Osyczka, A. (2015). Electronic connection between the quinone and cytochrome c redox pools and its role in regulation of mitochondrial electron transport and redox signaling. Physiological reviews, 95(1), 219-243. https://journals.physiology.org/doi/full/10.1152/physrev.00006.2014.

Schaible, A. M., Filosa, R., Temml, V., Krauth, V., Matteis, M., Peduto, A., ... \& Werz, O. (2014). Elucidation of the molecular mechanism and the efficacy in vivo of a novel 1, 4-benzoquinone that inhibits 5-lipoxygenase. British journal of pharmacology, 171(9), 2399-2412. https://bpspubs.onlinelibrary.wiley.com/doi/full/10.1111/bph.12592.

Sivasankar, C., Gayathri, S., Bhaskar, J. P., Krishnan, V., \& Pandian, S. K. (2017). Evaluation of selected Indian medicinal plants for antagonistic potential against Malassezia spp. and the synergistic effect of embelin in combination with ketoconazole. Microbial Pathogenesis, 110, 66-72. https://www.sciencedirect.com/science/article/abs/pii/S0882401016304387.

Sofowora, A., Ogunbodede, E., \& Onayade, A. (2013). The role and place of medicinal plants in the strategies for disease prevention. African journal of traditional, complementary and alternative medicines, 10(5), 210-229. https://www.ajol.info/index.php/ajtcam/article/view/92333.

Sousa, C. J. P., Prete, A. C. L., Gomes, A. G. P., de Castro, E. F. R., \& Ribeiro, C. H. M. A. (2021). Adverse drug events in hospitalized patients in Brazil: $\begin{array}{llllll}\text { Integrative literature } & \text { review. Research, } & \text { Society } & \text { and } & \text { Development, 10(4), } & \text { e3410413818-e3410413818. }\end{array}$ https://rsdjournal.org/index.php/rsd/article/view/13818/12389.

Sousa, E. T., Lopes, W. A., \& de Andrade, J. B. (2016). Sources, formation, reactivity and determination of quinones in the atmosphere. Quimica Nova, 39(4), 486-495. https://www.scielo.br/pdf/qn/v39n4/0100-4042-qn-39-04-0486.pdf.

Sreelatha, T., Kandhasamy, S., Dinesh, R., Shruthy, S., Shweta, S., Mukesh, D., ... \& Perumal, P. T. (2014). Synthesis and SAR study of novel anticancer and antimicrobial naphthoquinone amide derivatives. Bioorganic \& medicinal chemistry letters, 24(15), 3647-3651. https://www.sciencedirect.com/science/article/abs/pii/S0960894X14004375.

Yang, Y., Zhou, X., M. Xu, J. Piao, Y., Zhang, Z., Lin, L. Chen. (2017) $\beta$-lapachone suppresses tumour progression by inhibiting epithelial-to-mesenchymal transition in NQO1-positive breast cancers. Scientific Reports, 7 (1) . https://www.nature.com/articles/s41598-017-02937-0. 